\title{
Effect of Application of Brewery Waste Water on Growth and Yield of Maize Crop
}

\author{
H. R. Savitha ${ }^{1 *}$, C. A. Srinivasamurthy ${ }^{2}$, T. Bhagya Lakshmi ${ }^{1}$, \\ G. C. Shashishara ${ }^{1}$ and S. Bhaskar \\ ${ }^{1} U A S$, GKVK, Bangalore-65, India \\ ${ }^{2}$ Directorate of Research, CAU, Imphal, India \\ ${ }^{3}$ Department of Agronomy, Agro-Forestry and Climate Change, ICAR, New Delhi, India \\ *Corresponding author
}

\section{A B S T R A C T}

\section{Keywords}

Brewery waste water, Maize, Growth, Yield

\section{Article Info}

Accepted:

07 September 2019

Available Online:

10 October 2019
A field experiment was conducted to study the effect of brewery waste water on growth and yield of maize at United Breweries Ltd., Nelamangala, during rabi 2008, kharif 2009 and kharif 2010 on a sandy loam soil. Treatments consisted of three levels of nitrogen through brewery waste water $\left(1,1 \frac{1 / 2}{2}\right.$ and 2$)$. Application of $1 \frac{1 / 2}{2}$ times the recommended level of $\mathrm{N}$ through treated brewery waste water recorded maximum plant height $(188.7 \mathrm{~cm})$, number of leaves $(15.2)$, cob length $(22.7 \mathrm{~cm})$, cob circumference $(15.1 \mathrm{~cm})$, test weight $(24.7 \mathrm{~g})$, grain yield $(6.36 \mathrm{t} / \mathrm{ha})$ and stover yield (11.34 t/ha) followed by 2 times the recommended level of $\mathrm{N}$ through treated brewery waste water plant height $(185.1 \mathrm{~cm})$, number of leaves $(13.9)$, cob length $(16.8 \mathrm{~cm})$, cob circumference $(14.5 \mathrm{~cm})$, test weight $(24.1 \mathrm{~g})$, grain yield $(5.83 \mathrm{t} / \mathrm{ha})$ and stover yield (10.26 t/ha) were recorded during 2008, 2009 and 2010, respectively. Lowest plant height $(136.7 \mathrm{~cm})$, number of leaves $(8.5)$, cob length $(16.2 \mathrm{~cm})$, cob circumference $(12.3 \mathrm{~cm})$, test weight $(19.9 \mathrm{~g})$, grain yield $(3.68 \mathrm{t} / \mathrm{ha})$ and stover yield (6.36 t/ha) were recorded with farmers practice. The maximum available nutrients like nitrogen, phosphorus and potassium were recorded with farmers practice and lowest were observed in the treatment which receiving $1 \frac{1 / 2}{2}$ times the recommended level of $\mathrm{N}$ through treated brewery waste water during all the years.

\section{Introduction}

Pollution of soil and water bodies is a serious problem ever since man started disposing sewage and industrial effluents into water bodies and on land. The problem of pollution was accentuated due to rapid industrialization and spurt in human population. Breweries are agro-based industries, which produce the alcoholic drink, mainly beer. The main ingredients used in the brewing process are barley, hops, yeast and water. Sometimes other cereals are also used. All brewers follow the same basic process and have minor 
alterations such as varying the ingredients, the brewing period and temperature to obtain different types of beer. The steps involved are malting, mashing, boiling, fermentation, aging and finishing. The quantity of wastewater generated is about 3-3.2 liters per liter of beer and the total quantity of wastewater produced from the brewery unit is approximately around 10 lakh liters per day depending on the quantity of beer produce. When this wastewater is disposed off unscientifically on the land cause pollution of soil and water occurs. Therefore it is very essential to study the composition of brewery wastewater and the effect of its application on soil properties and crop growth.

\section{Materials and Methods}

The primary treated brewery waste water was collected from United Breweries Ltd., Nelamangala, located near Bengaluru (Karnataka), India, and was analysed for physico-chemical properties and nutrients composition by using standard methods (Manivasakam, 1987).

Experiments were conducted during rabi 2008 kharif 2009 and kharif 2010 in a sandy loam soil at United Breweries, Nelamangala, Karnataka to find out the response to application of diluted brewery waste water on growth and yield parameters of maize. The initial soil $\mathrm{pH}$ was neutral in reaction (7.29), normal in electrical conductivity $\left(0.18 \mathrm{dSm}^{-1}\right)$, medium in available nitrogen $(315.8 \mathrm{~kg} / \mathrm{ha})$, low in available phosphorus (13.70 kg/ha), low in available potassium (103.4 kg/ha) and medium in available sulphur (19.5 ppm) respectively. The experiment was laid out in a randomized complete block design (RCBD) with three replication and eight treatments with net plot size $1.2 \mathrm{~m} \times 1.2 \mathrm{~m}$. Treated and untreated brewery waste water was applied through different quantities at the time of planting, brewery waste water was applied through $\mathrm{N}$ basis. The recommended dose of $\mathrm{N}$, P, K @ 150:75:40 kg/ha, for this half dose of $\mathrm{N}$ and full dose of $\mathrm{P}$ and $\mathrm{K}$ were applied as a basal dose through urea, SSP and MOP respectively, and remaining $\mathrm{N}$ was applied one month after planting. Data on plant height, number of leaves, yield parameter and yield were recorded at different successive stages of plant growth after planting and an average was worked out for statistical analysis. Characterization of brewery waste water was given in Table 1.

\section{Results and Discussion}

The treated and untreated brewery waste water was collected from United Breweries Ltd., Nelamangala at bimonthly interval during November 2008 to October 2010. The results are presented in the Table 1.

Both treated and untreated brewery waste water was brown in color, treated brewery waste water was neutral in reaction $(\mathrm{pH}-7.17)$ and untreated brewery waste water was acidic in reaction ( $\mathrm{pH}-5.12)$. Electrical conductivity was 3.06 and $3.56 \mathrm{dSm}^{-1}$ in both treated and untreated brewery waste water respectively. The total $\mathrm{N}, \mathrm{P}_{2} \mathrm{O}_{5}$ and $\mathrm{K}_{2} \mathrm{O}$ contents of both the waste water were $0.25,0.003,0.03$ (TBWW) and 0.16, 0.002, 0.04 (UTBWW) per cent, respectively.

The $\mathrm{Na}, \mathrm{Ca}$ and $\mathrm{Mg}$ concentration of treated and untreated waste water were $0.54,2.54$, $1.45 \mathrm{mg} / \mathrm{l}$ and $0.79,2.10$ and $1.20 \mathrm{mg} / \mathrm{l}$ respectively. Chemical oxygen Demand and Chlorine contents were high in untreated brewery waste water than treated brewery water. Total solids content were 2.56 and $2.20 \%$ in both treated and untreated brewery waste water. The concentration micronutrients were low in brewery waste water $(\mathrm{Fe}, \mathrm{Zn}, \mathrm{Cu}$, $\mathrm{Mn}$, values were $16.2,2.45,0.52,1.42 \mathrm{mg} / \mathrm{l}$, respectively in treated brewery waste water and $\mathrm{Fe}, \mathrm{Zn}, \mathrm{Cu}, \mathrm{Mn}$, values were 13.4, 3.95, 
$0.45,1.20 \mathrm{mg} / \mathrm{l}$, respectively in untreated brewery waste water.

\section{Growth parameters}

The maximum plant height $(214 \mathrm{~cm})$ and number of leaves (13.3) were recorded in the treatment which receiving $1 \frac{1}{2}$ times the recommended level of $\mathrm{N}$ through treated brewery waste water followed by 2 times the recommended level of $\mathrm{N}$ through treated brewery waste water $(208.3 \mathrm{~cm}$ and 13.0$)$ at harvest. Significantly the lowest plant height $(189.7 \mathrm{~cm})$ and number of leaves $(12.3)$ were recorded with farmers practice (Table 2). Application of lower concentration (1 $1 / 2$ times $\mathrm{N}$ through waste water) of brewery waste water recorded maximum growth and yield parameters than higher concentration (2 times $\mathrm{N}$ through waste water) of brewery waste water (Kumar Suresh, 2005).

Application of brewery waste water was recorded highest growth parameters compared to control. This might be due to higher nutrient content in effluent water which helped in better expression of growth parameters Orhu Ehi Robert et al., (2005).

Table.1 Physico-Chemical properties of treated and untreated brewery waste water collected from United Breweries, Nelamangala, Karnataka

\begin{tabular}{|c|c|c|c|}
\hline \multirow{2}{*}{ SI. No } & Parameters & \multicolumn{2}{|c|}{ Mean } \\
\cline { 3 - 4 } & & Treated & Untreated \\
\hline 1. & $\mathrm{pH}(1: 2.5)$ & 7.17 & 5.12 \\
\hline 2. & EC $(\mathrm{dS} / \mathrm{m})(1: 2.5)$ & 3.06 & 3.56 \\
\hline 3. & Total nitrogen $(\%)$ & 0.25 & 0.16 \\
\hline 4. & Total phosphorus $(\%)$ & 0.003 & 0.002 \\
\hline 5. & Total potassium $(\%)$ & 0.03 & 0.04 \\
\hline 6. & Sodium $(\mathrm{mg} / \mathrm{l})$ & 0.54 & 0.79 \\
\hline 7. & Calcium $(\mathrm{mg} / \mathrm{l})$ & 2.54 & 2.10 \\
\hline 8. & Magnesium $(\mathrm{mg} / \mathrm{l})$ & 1.45 & 1.20 \\
\hline 9 & Chemical OxygenDemand $(\mathrm{mg} / \mathrm{l})$ & 1200 & 2100 \\
\hline 10. & Total solid $(\%)$ & 2.56 & 2.20 \\
\hline 11. & Chlorine $(\mathrm{mg} / \mathrm{l})$ & 45.7 & 59.3 \\
\hline 12. & Iron $(\mathrm{mg} / \mathrm{l})$ & 16.2 & 13.4 \\
\hline 13. & Zinc $(\mathrm{mg} / \mathrm{l})$ & 2.45 & 3.95 \\
\hline 14. & Copper $(\mathrm{mg} / \mathrm{l})$ & 0.52 & 0.45 \\
\hline 15. & Manganese $(\mathrm{mg} / \mathrm{l})$ & 1.42 & 1.20 \\
\hline
\end{tabular}


Table.2 Effect of application of brewery waste water (treated and untreated) on plant height and number of leaves of maize at harvest stage.

\begin{tabular}{|c|c|c|}
\hline \multirow[t]{2}{*}{ Treatments } & \multicolumn{2}{|c|}{ Harvest stage } \\
\hline & $\begin{array}{l}\text { Plant height } \\
\text { (cm) }\end{array}$ & $\begin{array}{l}\text { Number of } \\
\text { leaves }\end{array}$ \\
\hline$T_{1}:$ Farmers practice & 167.7 & 12.5 \\
\hline$T_{2}:$ rec. practice & 180.6 & 12.7 \\
\hline$T_{3}$ : rec. $\mathbf{N}$ through UBWW & 170.0 & 12.7 \\
\hline$T_{4}$ : rec. $N$ through $T B W W$ & 201.3 & 12.9 \\
\hline $\begin{array}{c}T_{5}: 1 \frac{1 / 2 \text { times rec. } N \text { through }}{\text { UBWW }} \\
\text { Un }\end{array}$ & 182.3 & 12.7 \\
\hline $\begin{array}{l}\mathrm{T}_{6}: 1 \text { 1/2 times rec. } \mathbf{N} \text { through } \\
\text { TBWW }\end{array}$ & 214.0 & 13.3 \\
\hline$T_{7}: 2$ times rec. $\mathrm{N}$ through $\mathrm{UBWW}$ & 188.3 & 12.8 \\
\hline $\mathrm{T}_{8}: 2$ times rec. $\mathrm{N}$ through $\mathrm{TBWW}$ & 208.3 & 13.0 \\
\hline SE.m \pm & 0.60 & 0.15 \\
\hline CD@5\% & 1.50 & 0.33 \\
\hline
\end{tabular}

Table.3 Effect of application of brewery waste water (Treated and untreated) on yield parameters and yield of maize

\begin{tabular}{|c|c|c|c|c|c|}
\hline Treatments & $\begin{array}{c}\text { Cob } \\
\text { length } \\
(\mathrm{cm})\end{array}$ & $\begin{array}{c}\text { Cob } \\
\text { circumference } \\
(\mathbf{c m})\end{array}$ & $\begin{array}{c}\text { Test } \\
\text { weight } \\
\text { ( g) }\end{array}$ & $\begin{array}{l}\text { Grain } \\
\text { yield } \\
\text { (t/ha) }\end{array}$ & $\begin{array}{c}\text { Stover } \\
\text { yield } \\
\text { (t/ha) }\end{array}$ \\
\hline $\mathrm{T}_{1}$ : Farmers practice & 17.3 & 14.9 & 21.1 & 4.25 & 6.80 \\
\hline$T_{2}:$ rec. practice & 17.5 & 14.8 & 22.0 & 4.50 & 7.50 \\
\hline$T_{3}:$ rec. $N$ through UBWW & 18.0 & 14.9 & 23.2 & 4.75 & 8.08 \\
\hline$T_{4}:$ rec. $N$ through TBWW & 22.4 & 16.6 & 25.1 & 5.75 & 10.1 \\
\hline $\begin{array}{c}T_{5}: 1 \frac{1}{2} \text { times rec. } N \text { through } \\
\text { UBWW }\end{array}$ & 20.1 & 14.9 & 23.9 & 5.08 & 8.58 \\
\hline $\begin{array}{c}T_{6}: 1 \text { 1/2 times rec. } N \text { through } \\
\text { TBWW }\end{array}$ & 25.3 & 16.9 & 25.4 & 6.50 & 11.2 \\
\hline$T_{7}: 2$ times rec. $N$ through UBWW & 21.0 & 15.4 & 24.4 & 5.25 & 9.43 \\
\hline $\mathrm{T}_{8}: 2$ times rec. $\mathbf{N}$ through $\mathrm{TBWW}$ & 23.0 & 16.8 & 25.3 & 6.17 & 10.7 \\
\hline SE.m \pm & 0.45 & 0.39 & 0.18 & 0.28 & 0.41 \\
\hline CD@5\% & 1.13 & 0.99 & 0.40 & 0.70 & 1.031 \\
\hline
\end{tabular}


Table.4 Available nutrient status $\left(\mathrm{kg} \mathrm{ha}^{-1}\right)$ of soil at harvest of maize crop as influenced by treated and untreated brewery waste water

\begin{tabular}{|c|c|c|c|c|c|c|c|}
\hline \multirow[t]{2}{*}{ Treatments } & $\mathbf{N}$ & $\mathbf{P}_{2} \mathbf{O}_{5}$ & $\mathrm{~K}_{2} \mathrm{O}$ & Zn & $\mathrm{Fe}$ & Mn & $\mathrm{Cu}$ \\
\hline & \multicolumn{3}{|c|}{$\left(\mathrm{kg} \mathrm{ha}^{-1}\right)$} & \multicolumn{4}{|c|}{$(\mathbf{p p m})$} \\
\hline $\begin{array}{c}T_{1}: \text { Farmers practice } \\
\text { (FYM @ } 5 \text { t/ha and N:P:K@102:115:0 kg/ha) }\end{array}$ & 212.4 & 13.90 & 148.90 & 0.44 & 6.45 & 5.63 & 1.03 \\
\hline$T_{2}:$ Recommended practice & 195.3 & 13.50 & 140.33 & 0.43 & 6.35 & 5.24 & 0.94 \\
\hline $\begin{array}{c}\mathrm{T}_{3} \text { : Recommended level of } \mathrm{N} \text { through untreated } \\
\text { brewery waste water }\end{array}$ & 180.7 & 13.20 & 130.3 & 0.41 & 6.22 & 4.83 & 0.80 \\
\hline $\begin{array}{c}\mathrm{T}_{4} \text { : Recommended level of } \mathrm{N} \text { through treated } \\
\text { brewery waste water }\end{array}$ & 165.4 & 13.20 & 107.27 & 0.39 & 5.74 & 4.15 & 0.69 \\
\hline $\begin{array}{l}T_{5}: 11 / 2 \text { times the recommended level of } \mathrm{N} \\
\text { through untreated brewery waste water }\end{array}$ & 175.9 & 13.10 & 125.77 & 0.40 & 6.06 & 4.35 & 0.72 \\
\hline $\begin{array}{c}\mathrm{T}_{6}: 11 / 2 \text { times the recommended level of } \mathrm{N} \\
\text { through treated brewery waste water }\end{array}$ & 155.3 & 13.00 & 90.30 & 0.35 & 5.33 & 3.93 & 0.65 \\
\hline $\begin{array}{c}\mathrm{T}_{7}: 2 \text { times the recommended level of } \mathrm{N} \text { through } \\
\text { untreated brewery waste water }\end{array}$ & 170.5 & 13.13 & 115.20 & 0.40 & 5.90 & 4.23 & 0.71 \\
\hline $\begin{array}{c}\mathrm{T}_{8}: 2 \text { times the recommended level of } \mathrm{N} \text { through } \\
\text { treated brewery waste water }\end{array}$ & 160.4 & 13.10 & 98.23 & 0.39 & 5.59 & 4.03 & 0.65 \\
\hline S.Em. \pm & 0.72 & 0.40 & 0.62 & 0.02 & 0.10 & 0.09 & 0.02 \\
\hline $\mathrm{CD}(\mathrm{p}=\mathbf{0 . 0 5})$ & 1.77 & NS & 1.55 & 0.03 & 6.45 & 0.17 & 0.04 \\
\hline
\end{tabular}

\section{Yield parameters}

Maximum yield parameter viz., cob length $(25.3 \mathrm{~cm})$, cob circumference $(16.9 \mathrm{~cm})$, test weight $(25.4 \mathrm{~g})$, grain $(6.50 \mathrm{t} / \mathrm{ha})$ and stover yield $(11.2 \mathrm{t} / \mathrm{ha})$ were recorded in treatment which receiving $1 \frac{1}{2}$ times the recommended level of $\mathrm{N}$ through treated brewery waste water followed by 2 times the recommended level of $\mathrm{N}$ through treated brewery waste water (Table 3). The significant difference were observed in control that recorded lowest cob length $(17.3 \mathrm{~cm})$, cob circumference $(14.8 \mathrm{~cm})$, test weight $(21.1 \mathrm{~g})$, grain $(4.25 \mathrm{t} / \mathrm{ha})$ and stover yield (6.80 t/ha). Significantly higher grain and stover yield were obtained in the application of treated waste water compare to untreated waste water and control.

The increased yield parameters and yield in brewery waste water was might be attributed to This might be due to addition of some nutrients required for plant growth and development supplied through brewery waste water when applied as soil application. Similar results were also obtained by Himabindu and Jagonmohan Reddy (2005).

\section{Available nutrients}

The maximum available nutrients like nitrogen (212.4 kg/ha), Phosphorus (13.9 $\mathrm{kg} / \mathrm{ha})$, potassium $(148.90 \mathrm{~kg} / \mathrm{ha})$, zinc $(0.44$ ppm), iron (6.45 ppm), manganese (5.63 ppm) and copper (1.03 ppm) were recorded with farmers practice and lowest major and micro nutrients are nitrogen $(155.3 \mathrm{~kg} / \mathrm{ha})$, phosphorus (13.0 $\mathrm{kg} / \mathrm{ha})$, potassium $(90.30 \mathrm{~kg} / \mathrm{ha})$, zinc $(0.35 \mathrm{ppm})$, iron $(5.33$ ppm), manganese (3.93 ppm) and copper (0.65 ppm) were observed in the treatment which receiving $1 \frac{1}{2}$ times the recommended level of $\mathrm{N}$ through treated brewery waste water (Table 4). This might be due to greater uptake by maize crop and also translocation of nutrients to various plant parts like stem, leaves and corn. 
In brewery waste water experiment, application of treated waste water recorded maximum growth and yield compare to untreated brewery waste water and control. Application of $1 \frac{1 / 2}{2}$ times the recommended level of $\mathrm{N}$ through treated brewery waste water recorded maximum plant growth (plant height and number of leaves) and yield parameters (cob length, cob circumference, test weight, grain yield and stover yield) compare to untreated waste water.

Significantly lower growth and yield parameters were recorded in the control. But in available nutrients, maximum major and micro nutrients were recorded in farmers practice and lowest were observed in the treatment which received $1 \frac{1}{2}$ times the recommended level of $\mathrm{N}$ through treated brewery waste. Application of brewery waste water to soil resulted in improvement on soil properties and crop growth than control (with out application of brewery waste water).

\section{References}

Kumar Suresh, 2005.Impact of paper mill effluent on seed germination and seedling growth of Phaseolus aureus C.V. Pant M- 4. Flora Fauna. 11(2): 189-193.

Himabindu, T., Jaganmohan Reddy, K., 2005.Effect of paper board mill effluents on biochemical characteristics of rice (Var. Swarna mahsuri). Nature Environment Pollution Technology. 4(4): 617-619.

Orhu Ehi Robert, Osaigbovo, Agbonsalo Ulamen, Vwioko, Dennis Emuejevoke, 2005. Growth of maize (Zea mays L.) and changes in some chemical properties of an ultisol amended with brewery effluent. African Journal of Biotechnology. 4 (9): 973-978.

\section{How to cite this article:}

Savitha, H. R., C. A. Srinivasamurthy, T. Bhagya Lakshmi, G. C. Shashishara and Bhaskar, S. 2019. Effect of Application of Brewery Waste Water on Growth and Yield of Maize Crop. Int.J.Curr.Microbiol.App.Sci. 8(10): 853-858. doi: https://doi.org/10.20546/ijcmas.2019.810.098 